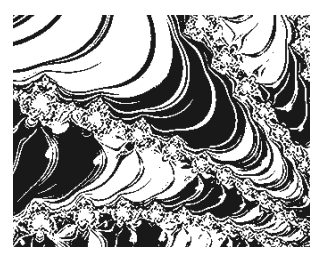

https://doi.org/10.5559/di.30.2.07

\title{
HOW HAS THE COVID-19 EPIDEMIC CHANGED DRUG USE AND THE DRUG MARKET IN SLOVENIA?
}

Matej SANDE

Faculty of Education, University of Ljubliana, Ljubliana, Slovenia

Simona ŠABIĆ, Mina PAŠ, Marko VERDENIK Association DrogArt, Ljubljana, Slovenia

UDK: 159.913(497.4):[616.98:578.828COVID-19]:343.575 178.8(497.4):[616.98:578.828COVID-19]

Izvorni znanstveni rad

Primljeno: 11. 1. 2021.

The purpose of our study was to explore the effect of the COVID-19 epidemic on drug use, the drug market and the availability of help and support in Slovenia. Through an online questionnaire, we collected a non-representative sample of 680 people who used drugs before and during the epidemic in 2020. The results showed the use of illicit drugs and alcohol has reduced. A significant increase in the frequency of use has only been detected in marijuana. The most prominent changes in the drug market were the reduced number of drug dealers and lower availability of certain drugs. Accessibility to drug services has been reduced and respondents also had significant financial consequences due to loss of work. Due to decreased availability of sources of support at the time of the epidemic, adjustments to services for drug users are necessary before the end of the COVID-19 pandemic in terms of promoting online interventions and maintaining contact with users when the services are not physically accessible.

Keywords: COVID-19, drug market, drug services, mental distress, drug use

Matej Sande, University of Ljubliana, Faculty of Education, Department of Social Pedagogy, Kardeljeva ploščad 16, 1000 Ljubliana, Slovenia

E-mail: matej.sande@pef.uni-li.si 
The new coronavirus disease (COVID-19) pandemic of 2020 has had a significant impact on human life and mental and physical health in most countries around the world (Torales et al., 2020). The World Health Organization declared a COVID-19 pandemic on 11 March 2020 (Oosterhoff et al., 2020); an epidemic was declared in Slovenia on 12 March 2020, and measures related to the epidemic were in force until the end of May (ZIUZEOP, 2020). The consequences of the epidemic were apparent in the public health system, which was under extreme pressure (Remuzzi, A. \& Remuzzi, G., 2020), and there were also noticeable psychological consequences of social isolation, physical distancing, restrictions on movement and quarantine (Oosterhoff et al., 2020; Torales et al., 2020; Brooks et al., 2020). Despite state aid, the pandemic has and will continue to cause significant economic consequences, as it has affected all economic sectors (Nicola et al., 2020), which will, among other things, lead to financial difficulties and higher unemployment after the epidemic (Napovedi makroekonomskih gibanj v Sloveniji, 2020). The social and economic impacts of the epidemic will be particularly noticeable among the most vulnerable sections of the population, including people who use drugs.

Due to specific circumstances of drug use, such as sharing of utensils, reduced physical distancing during use, and associated health problems, users are exposed to additional risks of transmission of infections (EMCDDA, 2020a). Infection with the SARS-CoV-2 coronavirus can have greater consequences in people with chronic diseases, especially respiratory diseases. Vulnerable groups may also include high-risk drug users, for example heroin smokers who have been found to suffer from chronic obstructive pulmonary disease and asthma (Mitchell et al., 2016; Palmer et al., 2012). According to some studies (Thylstrup et al., 2015; Kim \& Park, 2019) cardiovascular diseases may also be present in people who inject drugs or use cocaine regularly. People who inject drugs and are infected with the new coronavirus may also be at an increased risk of overdosing (Me et al., 2020). Given that people who use drugs, in comparison with the general population, are more likely to also be smokers (Richter et al., 2002), there may also be a higher risk of complications in the event of infection in this regard. In response to the described risks, the EMCDDA issued recommendations for reducing the risk of infection among people who use drugs and recommendations for the operation of drug services during the epidemic (EMCDDA, 2020a; Drev et al., 2020).

According to preliminary results available so far (EMCDDA, $2020 \mathrm{~b}$ ), drug use decreased in the first three months of the 
DRUŠ. ISTRAŽ. ZAGREB GOD. 30 (2021), BR. 2, STR. 313-332

SANDE, M. ET AL.: HOW HAS THE..
COVID-19 pandemic in Europe, while alcohol use increased. The most significant change was detected in the use of cocaine and MDMA, which was related to the closure of nightclubs and bars and the measures related to restriction of movement.

In addition to the impact on users and drug services, the pandemic has also had an impact on the EU drug market due to interrupted market channels and the closure of borders. The EMCDDA and Europol survey (EMCDDA and Europol, 2020) during the COVID-19 epidemic analyzed the assessments of 29 experts from 22 member states in order to monitor the impact of the pandemic on the drug market and detected changes such as, for example, issues with the availability of some drugs and rising prices of some illicit drugs on drug markets in the EU. The data collected by UNODC (Me et al., 2020) similarly indicate a shortage and a rise in prices of some drugs. They also report a decline in drug purity and possible changes in drug use due to the market shortage. Some EU countries have reported that a shortage of heroin in the market could result in users switching to fentanyl. Additionally, they report a noticeable rise in the price of benzodiazepines and an increase in their use, as well as dangers for users with difficult access to substitution therapy and needle exchange programmes.

The main purpose of our study, conducted by the DrogArt Association, was to identify changes in the characteristics of drug use and changes in the drug market among people who used drugs more often and were going out more frequently before the COVID-19 epidemic. The research stems from the organization's need to adapt its programmes and understand the needs of people who use drugs during the epidemic.

During the first wave of the pandemic in Slovenia, public life changed completely, public transport was stopped, educational institutions were closed, and socializing was restricted. Our starting point was that the described limitations probably changed the general well-being of people, as well as the ways of socializing and the characteristics of drug use. Our hypothesis was that increased mental distress during the epidemic would be linked to a higher frequency or higher amounts of legal and illegal drug use. The hypothesis has been established on the basis of the links between, for example, depressed mood and increased alcohol use (Awaworyi Churchill \& Farrell, 2017), as well as stressful events and the use of drugs (Vulić Prtorić \& Macuka, 2004; Sinha, 2008) in order to examine whether depressed mood and anxiety during the epidemic may be linked to increased use of legal and illegal drugs. 
DRUŠ. ISTRAŽ. ZAGREB GOD. 30 (2021), BR. 2, STR. 313-332

SANDE, M. ET AL.: HOW HAS THE..

\section{METHOD}

\section{Participants}

All public events, concerts and parties were prohibited by decree, and socializing of people and crossings between municipalities were also restricted (Odlok o začasni splošni prepovedi gibanja in zbiranja ljudi na javnih krajih, površinah in mestih v Republiki Sloveniji ter prepovedi gibanja izven občin, 2020). The operating methods of NGOs and other organizations working with people who use drugs in Slovenia changed as well. During the first wave of the epidemic, day centres were closed or their contact with users was limited, psychosocial assistance was available to a lesser extent, and the replacement of equipment in harm reduction programmes took place in an adapted manner. Day outreach work at DrogArt in Ljubljana was also similarly limited, and the outreach work of the organization in nightlife was interrupted due to the restrictions. Access to users in the field in harm reduction programmes at the DrogArt association was no longer possible, and the info point was closed. To ensure contact with users, we started developing online interventions at DrogArt (e.g. virtual counselling, virtual "Discord" day centre, online interventions over social media). Various sources from outreach workers at DrogArt indicated that, regardless of the socializing restrictions, parties and gatherings of young people still took place in public and private spaces. We were also interested in whether changes occurred in the retail drug market due to interrupted market routes, limited access and restrictions on movement between municipalities. Due to the changed circumstances, our research team anticipated that the psychosocial distress of people who use drugs increased and that access to assistance programmes was limited. On the basis of the results, we planned possible changes and new ways of working for different programmes in the organization.

The aim of the cross-sectional study was to include people who used drugs more often and were going out more frequently before the epidemic. Based on our previous research (Sande, 2020), 'more frequently' would mean at least once every two weeks or more often. Using an online anonymous questionnaire, we included 1096 respondents in the sample, of which 710 completed the survey questionnaire in its entirety. Given that we wanted to include respondents who had used drugs before the declared epidemic in 2020, which was also published in the research notice, we excluded respondents who did not use drugs from the final sample, as well as 
DRUŠ. ISTRAŽ. ZAGREB GOD. 30 (2021), BR. 2, STR. 313-332

SANDE, M. ET AL. HOW HAS THE..

\section{Data collection}

\section{Data analysis}

those who did not fully complete the basic demographic data at the end of the questionnaire. In this way, we excluded 26 respondents who did not use drugs in 2020 and 4 who did not fully complete the demographic data. The final sample comprised of 680 respondents who reported drug use and going out before the COVID-19 epidemic.

The survey was published in the period from 14 April 2020 to 3 May 2020, during the COVID-19 pandemic. The first COVID-19 epidemic was declared in Slovenia from 12 March 2020 to 31 May 2020. At the time of the epidemic, there was a restriction on movement between municipalities and a restriction on the gathering of people in public areas. Prior to the publication of the questionnaire, a small pilot test $(n=30)$ was conducted to assess the comprehensibility of the questions and to collect comments on the questionnaire. On the basis of the review of the received comments, we corrected and adjusted the questionnaire and prepared its final form, which was published on the 1KA web platform. The link to the questionnaire was published on official DrogArt Instagram and Facebook profiles and the DrogArt web page. The highest number of clicks on the survey came from social networks (largely from mobile devices).

We compiled the questionnaire from the questions and scales we had used in our past research (Sande, 2016, 2020) on drug and alcohol use and added some new questions and scales for assessing mental and physical well-being during the epidemic. It comprised 24 questions or scales, which included four or five levels of answers ranging from "never" to "very often" in questions about visiting clubs, bars and public areas, or a Likert-type scale in assessing mental and physical well-being from "significantly worsened" to "significantly improved". The average time to complete the questionnaire was 8 minutes.

The basic data was displayed using descriptive statistics. We used t-tests for independent samples to show results on gender differences in drug use and distress of respondents. To test the hypotheses about the connection between mental distress and drug use, we used the chi-square test. The analyses presented throughout the text show valid percentages, with no missing answers. In some displays, where we were only interested in users of certain drugs, the analyses were done on a smaller number of users of that respective drug. 


\section{Sample characteristics}

In the final sample of 680 persons, $58.7 \%$ were women and $40.6 \%$ men, and $0.7 \%$ identified their gender as other. The mean age in the sample was 25 years $(M=23.0, M o=21)$. The age range in the sample was between 16 and 69 years. 59.9\% of persons in the sample were under 25 years of age, and $7.9 \%$ were over 35 years of age. Most of the respondents came from the area of the Ljubljana city municipality $(30.2 \%)$. By statistical region, the majority of respondents were from the Osrednjeslovenska region $(44.0 \%)$, the Gorenjska region $(10.9 \%)$, the Podravska region $(8.2 \%)$, the Savinjska region $(7.3 \%)$ and the Koroška region (6.5\%). Other statistical regions represented under $5.0 \%$. The sample consisted mostly of students $(42.5 \%)$ and secondary school students $(13.7 \%)$. At the time of the survey (and the epidemic), 23.0\% of respondents were employed, of which $12.7 \%$ worked from home. $10.0 \%$ of the people included in the sample were waiting for work due to the epidemic. Also, 5.9\% of respondents were unemployed due to the epidemic, and $4.7 \%$ were unemployed for a longer period of time.

Before the epidemic and the quarantine, most of the respondents would usually "go out" to bars $(68.3 \%)^{1}$ or to parks and other open public spaces (69.7\%). 41.2\% of the respondents would go to clubs "often" and "very often", $47.9 \%$ to "private parties" and $28.4 \%$ to "mass parties". Thus, the sample included people who would "go out" relatively often before the epidemic.

\section{The distress of respondents during the COVID-19 epidemic}

Respondents were asked about how their well-being has changed since the epidemic was declared and what types of issues or distress they experienced more often during the epidemic.

Mental well-being remained unchanged in 36.7\%, significantly worsened in $9.4 \%$, worsened in $35.3 \%$, improved in $14.4 \%$ and significantly improved in $4.1 \%$ of respondents. There were statistically significant differences between the genders in terms of mental well-being ( $\mathrm{t} 634.058=-2.058, p<0.05)$, and the mental well-being of the women in the sample deteriorated slightly more during the epidemic.

We examined the individual types of distress of the respondents in more detail in comparison with the time before the epidemic. Respondents were more likely to feel anxious (41.8\%), depressed $(40.7 \%)$ and lonely $(47.8 \%)$ than they did before the epidemic. During the quarantine, almost a quarter of the respondents $(24.5 \%)$ argued more with their partners, family 
DRUŠ. ISTRAŽ. ZAGREB GOD. 30 (2021), BR. 2, STR. 313-332

SANDE, M. ET AL. HOW HAS THE..

members and people with whom they lived. There were no statistically significant differences between the sexes in all of these comparisons.

Physical well-being remained unchanged in $36.8 \%$, significantly worsened in $5.8 \%$, worsened in $29.5 \%$, improved in $22.9 \%$ and significantly improved in $5.0 \%$ of the respondents. There are no statistically significant differences between the genders in terms of changes in physical well-being.

An increase in sleep-related problems was experienced by $35.1 \%$ of the respondents, and men had greater sleep problems than women $(\mathrm{t} 668=2.960, p<0.01)$. During the epidemic, $38.0 \%$ of the respondents were less satisfied with their sexual life.

An increase in financial problems during the epidemic was reported by $27.8 \%$ of the respondents.

Given that the declared epidemic and quarantine have significantly affected our lives, we also added a special question to determine whether the respondents, in their opinion, experienced any of the reported distress due to the COVID-19 epidemic, or whether the distress came from their part. This question had several possible answers; individuals were able to select the type(s) of distress. Chart 1 shows that the vast majority did not experience any distress due to the epidemic. For others, most of the distress was related to unemployment, drug-related problems, and domestic violence.

Respondents had the option to list under "other" the types of distress not included in the list. 25 respondents listed their own distresses, including financial distress, anxiety, eating disorders, suicidal thoughts, self-injurious behaviour, psychological violence, boredom, and relationship problems. Individual respondents also stated that they had been left without an apartment due to the epidemic and had to move back in with their families, and that their already poor mental health had deteriorated further because of this.

\section{Characteristics of the use of illicit drugs and alcohol in the period before and during the COVID-19 epidemic}

Our research explored changes in drug use during the COVID-19 epidemic, characteristics of drug use, and reasons for a possible increase in use. Given that the epidemic was declared in mid-March, we wanted to know which drugs were used this year before the epidemic (two and a half months in 2020 before the declared epidemic) and during the epidemic.

The most commonly used drugs before the epidemic (Table 1) were alcohol, marijuana, and MDMA. Compared to the results of a similar research from 2018 (Sande, 2020) about 
DRUŠ. ISTRAŽ. ZAGREB GOD. 30 (2021), BR. 2, STR. 313-332

SANDE, M. ET AL.: HOW HAS THE..

- TABLE 1

Use of illicit and licit drugs before and during the epidemic in 2020 in our sample $(n=680)$

\section{(1) TABLE 2}

Frequency of use of certain illicit and licit drugs by users in our sample noticeable increase in the use of benzodiazepines, ketamine and hallucinogens.

During the epidemic, the most commonly used drugs were alcohol, marijuana and cocaine. The use of illicit and licit drugs was lower in the sample than before the epidemic. The use of alcohol (18.4\%) and marijuana (19.9\%) decreased the least, while the use of MDMA and GHB/GBL decreased the most (by $72 \%$ ).

We asked the respondents whether the frequency of their use had changed during the epidemic. We posed this question only to those respondents who had indicated that they used individual drugs during the epidemic. The frequency increased only in marijuana (Table 2 ), which $43.5 \%$ reported using more frequently during the epidemic.

\begin{tabular}{lcc}
\hline Drug use & $\begin{array}{c}\text { Used before } \\
\text { the epidemic } \%\end{array}$ & $\begin{array}{c}\text { Used during } \\
\text { the epidemic \% }\end{array}$ \\
\hline Alcohol & 91.0 & 74.3 \\
Marijuana & 75.3 & 60.3 \\
Cocaine & 38.7 & 18.8 \\
MDMA & 41.9 & 11.9 \\
Amphetamines & 30.3 & 12.4 \\
Hallucinogens (LSD, mushrooms) & 24.6 & 12.1 \\
Ketamine & 13.7 & 5.0 \\
Benzodiazepines & 11.6 & 7.4 \\
GHB/GBL & 6.9 & 1.9 \\
Prescribed psychiatric medication & 5.1 & 3.5 \\
3-MMC & 2.6 & 1.0 \\
Heroin & 1.6 & 1.2 \\
\hline
\end{tabular}

For the other drugs in Table 2, most of the respondents reported less frequent use than before the epidemic, or the use was unchanged. The majority used alcohol less often (42.5\%) than before the epidemic, and slightly less than a third of respondents used it more often.

\begin{tabular}{lrccc}
\hline $\begin{array}{l}\text { Did the frequency of your drug use } \\
\text { change during the Covid-19 epidemic? }\end{array}$ & $n$ & $\begin{array}{c}\text { I use } \\
\text { less often } \%\end{array}$ & $\begin{array}{c}\text { The frequency } \\
\text { has not changed \% }\end{array}$ & $\begin{array}{c}\text { I use } \\
\text { more often \% }\end{array}$ \\
\hline Alcohol & 485 & 42.5 & 28.5 & 29.0 \\
Marijuana & 382 & 18.6 & 38.0 & 43.5 \\
Cocaine & 115 & 50.4 & 32.2 & 17.4 \\
MDMA & 68 & 51.5 & 36.8 & 11.8 \\
Amphetamines & 72 & 52.8 & 26.4 & 20.8 \\
Hallucinogens (LSD, mushrooms) & 58 & 31.0 & 48.3 & 20.7 \\
\hline
\end{tabular}

Respondents who indicated that they used illicit and licit drugs more often during the epidemic $(n=286)$ were also asked what the main reasons for this were. Three quarters of 
DRUŠ. ISTRAŽ. ZAGREB GOD. 30 (2021), BR. 2, STR. 313-332

SANDE, M. ET AL.: HOW HAS THE... them indicated that boredom was the main reason. Other stated reasons for increased use include anxiety (37.4\%), restlessness $(36.4 \%)$, depression (30.4\%) and feelings of alienation $(29.0 \%)$.

We were also interested in the changes in the amount of illicit and licit drugs from Table 1 which the respondents used on a single occasion. Among the most commonly used drugs during the epidemic (alcohol, marijuana and cocaine), only the amount of marijuana increased among users. $40.7 \%$ of users indicated that they used larger quantities during the epidemic. Alcohol (46.1\%) and cocaine (41.6\%) were used in smaller quantities. Among other reasons, respondents indicated that they had more time during the quarantine and were less stressed.

We were interested in the occasions on which respondents used drugs during the epidemic. Respondents had the option to mark several occasions. Just over half of the respondents used drugs at home alone during the epidemic (52.4\%). One third indicated that they used alone outdoors $(32.5 \%)$ or at home with people they live with (34.6\%). A smaller proportion $(12.8 \%)$ indicated that they used at online parties.

The second type of occasion is important from the point of view of infection prevention, since it is associated with the possibility of virus transmission. Just under one third of the respondents indicated in the above question that they had used drugs outside, with people they did not live with, and $18.5 \%$ indicated that they used at private parties with the same group of people. $4.6 \%$ of the respondents used drugs at private parties with different people. Two of the respondents pointed out in the comments that they used drugs along with others, but did not share marijuana cigarettes.

We asked those who attended private parties how many such parties they attended. Most of those who attended parties attended two $(24.0 \%)$ or three parties $(20.0 \%)$. The maximum number of parties attended by an individual respondent during the epidemic was 20.

The majority of respondents $(61.9 \%)$ used drugs with two to four people in the same room during the epidemic. $8.3 \%$ of respondents shared with five to ten people, and $0.7 \%$ with more than ten. The rest indicated that they used by themselves $(29.1 \%)$.

$8.5 \%$ of respondents stopped using drugs due to the epidemic. We also inquired about the main reasons for cessation. From the open answers, we summarized three main reasons, namely that they lived at home with their parents and thus could not use drugs, that their use was a matter of socializing and they did not use by themselves, and because their use was related to nightlife and there were no open clubs or parties. 
DRUŠ. ISTRAŽ. ZAGREB

GOD. 30 (2021), BR. 2,

STR. 313-332

SANDE, M. ET AL.: HOW HAS THE...
We also examined the main ways to reduce the health risks of drug use during the epidemic. The main methods indicated by half of the respondents in the sample were ensuring sufficient sleep and rest $(50.0 \%)$, regular and healthy diet $(49.1 \%)$ and maintaining good physical condition $(42.2 \%)$. A smaller number of respondents indicated that they did not use drugs in a bad mental state during the epidemic (26.6\%), that they took sufficient breaks between uses (24.7\%), did not use several drugs at the same time $(23.1 \%)$, did not use out of boredom $(22.1 \%)$, that they started with small doses $(16.8 \%)$ and that they accurately measured the amounts before use $(13.1 \%)$.

In regard to the practice of hygiene in drug use, just under a quarter of people who use drugs indicated that they did not share rolls of tobacco and marijuana with others $(23.7 \%)$ during the epidemic, that they thoroughly washed or disinfected their hands before handling drugs (22.6\%), and that they used their own clean sniffing accessories (21.9\%). Only 4.0\% of the respondents in the sample indicated that they did not take into account any of the above.

To measure the reach of drug risk reduction information at the time of the epidemic, we were interested in where all the users got their information. Just over half of the respondents indicated that they did not receive information from any source $(53.2 \%)$. Others indicated that they received information on the internet $(22.5 \%)$, through DrogArt ${ }^{2}(22.1 \%)$, friends $(15.7 \%)$, other non-governmental organizations $(3.5 \%)$, health care institutions $(3.5 \%)$ and from parents $(2.8 \%)$.

We were also interested in how respondents perceived changes in the availability of help and support during the epidemic. There are noticeable differences in the accessibility of the various institutions that provide support. Thus, the respondents estimated that it was more difficult for them to access health care institutions (55.4\%), non-governmental organizations $(27.5 \%)$ and social work centres $(26.1 \%)$ during the epidemic. Given the situation related to the "quarantine" and the epidemic, respondents estimated that the help of friends was also more difficult to reach $(44.6 \%)$. The respondents felt that support was more easily accessible from their families and partners. Family support was rated as being more accessible by $18 \%$ of the respondents, equally accessible by $47.2 \%$ of the respondents, and less accessible by $17.9 \%$ of the respondents. Partner support was rated more accessible by $8.9 \%$ of the respondents, equally accessible by $31.8 \%$ of the respondents, and less accessible by $15.2 \%$ of the respondents. The other respondents answered that they do not need the listed types of help or that the question does not apply to them. 
DRUŠ. ISTRAŽ. ZAGREB GOD. 30 (2021), BR. 2,

SANDE, M. ET AL. STR. 313-332 HOW HAS THE..
The ways in which respondents in the sample obtained drugs during and before the epidemic. several possible answers $(n=680)$
TABLE 3 This question had

Our hypothesis about the link between mental distress and a higher frequency and larger amounts of drug use could only be proven for the case of alcohol use. We examined individual types of mental distress, namely depression, anxiety and loneliness. The association between higher levels of alcohol use and higher frequency of use during the epidemic was shown only for alcohol in depression, but not for other commonly used drugs in the sample. Thus, we can reject the null hypothesis and accept the hypothesis of the association of more frequent alcohol use $\left(\chi^{2}(4)=12.608, p<0.05\right)$ and higher amounts of alcohol $\left(\chi^{2}(4)=14.717, p<0.01\right)$ with a greater feeling of depression during the epidemic. In the case of illicit drugs, however, we accept the null hypothesis.

\section{Changes in the retail drug market during the epidemic}

One of the main objectives of the research was to monitor the drug market and changes in the drug market during the epidemic. Table 3 shows the changes in the purchase methods of the respondents in the sample at the time of the epidemic and before it, featuring the most common purchase methods. The most common ways to purchase are other friends, dealers, stock and home delivery by the dealer. The purchase of drugs at parties has understandably declined. Less frequently selected modes of access to drugs not shown in Table 3 included the internet/darknet $(2.8 \% / 2.4 \%),{ }^{3}$ own production $(4.3 \% / 4.0 \%)$ and access to drugs prescribed by a doctor $(2.8 \% / 2.5 \%)$.

\begin{tabular}{lcc}
\hline $\begin{array}{l}\text { How would you } \\
\text { usually obtain drugs ... }\end{array}$ & $\begin{array}{c}\text { before the } \\
\text { epidemic \% }\end{array}$ & $\begin{array}{c}\text { during the } \\
\text { epidemic \% }\end{array}$ \\
\hline Through friends & 66.9 & 49.1 \\
Visiting a reseller & 40.9 & 26.6 \\
At a party & 27.8 & 3.2 \\
I have stock & 25.1 & 27.4 \\
The reseller delivers them to my home & 16.6 & 15.0
\end{tabular}

In addition to the ways in which users accessed drugs, we also explored the availability of drugs during the epidemic. The majority of respondents in the sample reported that alcohol was equally accessible as before the epidemic $(81.0 \%)$, while a smaller proportion indicated that it was either less $(8.2 \%)$ or more accessible $(6.7 \%)$. According to respondents, the availability of the other two most commonly used illicit drugs during the epidemic (marijuana and cocaine) increased. Marijuana was less accessible for $26.8 \%$ of the respondents, and cocaine was less accessible for $13.7 \%$. In terms of illicit drugs, marijuana was rated as being more accessible than before the epidemic by $47.1 \%$ of the respondents, while MDMA, am- 
DRUŠ. ISTRAŽ. ZAGREB GOD. 30 (2021), BR. 2, STR. 313-332

SANDE, M. ET AL.: HOW HAS THE...

○ TABLE 4

Changes in the drug market according to respondents. This question had several possible answers $(n=680)$ phetamines, and hallucinogens were rated as less accessible.

Table 4 presents the changes in the drug market observed by respondents in comparison with the time before the epidemic. The majority of respondents indicated that they did not notice any changes, and a quarter noted a smaller number of dealers and a shortage of certain drugs. A small number of respondents $(13.7 \%)$ report an increase in drug price.

Changes in the drug market that you observed during

the epidemic compared to the period before the epidemic $\%$

I did not notice any changes

47.5

Smaller number of resellers $\quad 26.3$

Shortage of certain drugs $\quad 25.3$

Higher drug price $\quad 13.7$

The quality of drugs has decreased $\quad 7.8$

Possibility to buy only smaller quantities at a time $\quad 7.6$

Possibility to buy only larger quantities at a time $\quad 7.1$

More resellers $\quad 4.0$

The quality of drugs has increased $\quad 2.9$

Lower drug price $\quad 2.1$

Emergence of new drugs $\quad 1.5$

When interpreting and comparing the results of our research, we must take into account that the sampling was not representative and the results cannot be generalized. We included a specific group of people who used drugs and were "going out" more frequently before the epidemic in 2020 and who followed the DrogArt social media profiles and web page. Despite the limitations, the results can provide us with insight into the changes in drug use and the drug market during the epidemic in Slovenia. On the basis of the findings, we can plan appropriate measures and responses, both at the level of assistance programmes and at the level of decision-makers. In doing so, however, we must take into account that the proposed measures can only be very limited due to the non-representative nature of the sample and the fact that respondents were accustomed to the use of Internet and social media.

In our sample, mental well-being deteriorated the most during the epidemic, and respondents felt anxious, depressed, and lonely more often than in the period before the epidemic. According to predictions, the consequences of mental health problems due to the COVID-19 epidemic may have further longer-term consequences in the form of long-term health problems, isolation and stigma (Torales et al., 2020), which will need to be addressed by encouraging entry into the psy- 
DRUŠ. ISTRAŽ. ZAGREB GOD. 30 (2021), BR. 2, STR. 313-332

SANDE, M. ET AL. HOW HAS THE.. chosocial support network in order to mitigate the consequences of the epidemic, especially among vulnerable groups. In addition to boredom, respondents cited anxiety, depression, and feelings of alienation as reasons for their increase in drug use during the epidemic, which can be linked to the findings of previous research on the connection between anxiety and drug use (Smith \& Book, 2008).

In addition to mental health issues, a quarter of respondents reported having more financial problems during the epidemic than before the epidemic. One of the findings of the study was that the epidemic had significant financial consequences for respondents at the time of its duration. In addition to financial difficulties, a tenth of the sample was waiting for work, and $5.9 \%$ became unemployed due to the epidemic. Given that our sample included mostly students, who may also have had losses due to the decline in student work, we must put these results into perspective. If we take into account only the employed people in the sample, $40.9 \%$ of them suffered financial repercussions due to waiting for work or losing their job. The government of the Republic of Slovenia attempted to mitigate some of these impacts by taking measures already during the epidemic to contain its consequences, which will probably be perceptible for a longer period of time, especially among the most vulnerable groups. Projections for economic growth in Slovenia in 2020 under a milder scenario (excluding a second wave of the epidemic) indicate a decline in economic activity ${ }^{4}$ and an increase in the unemployment rate by less than one percentage point to $5.4 \%$, which means a loss of employment for about 10,000 employees (Napovedi makroekonomskih gibanj v Sloveniji, 2020).

The use of illicit drugs and alcohol in our sample decreased during the epidemic. The reduction in illicit drug use in our sample is in line with the preliminary findings of EMCDDA (2020c) regarding drug use in the first three months of the pandemic in Europe. There is also a consistent reduction in MDMA and cocaine use associated with the closure of clubs and discos and restrictions on movement and gathering during the pandemic (EMCDDA, 2020c; Winstock et al., 2020). The frequency of use increased significantly only in marijuana, and less so in other illicit drugs and alcohol. In the latter, the frequency of use increased in slightly less than a third of respondents, which is less than the increase observed in the preliminary results of the GDS COVID-19 study (Winstock et al., 2020). The increased use of marijuana in our sample is consistent with the results of the aforementioned study (Winstock et al., 2020), where the main reasons for the increase in use were more spare time and boredom. We were not able to 
DRUŠ. ISTRAŽ. ZAGREB GOD. 30 (2021), BR. 2, STR. 313-332

SANDE, M. ET AL.: HOW HAS THE... prove our hypothesis about the association between greater mental distress during the epidemic and greater use of illicit drugs. An association was shown only in depression and more frequent use of alcohol, and separately in the use of larger amounts of alcohol during the epidemic, which can also be linked to the findings of other studies (Rehm et al., 2003; Schuckit, 2006; Awaworyi Churchill \& Farrell, 2017). The use of illegal drugs in our sample is understandably higher than in the general population, since these were young people who would often get involved in nightlife before the epidemic. Thus, the usage of the three most-used drugs was significantly higher in our sample than, for example, in the HBSC study of the general population (Jeriček Klanšček et al., 2019), where cannabis had been used by $42.4 \%$, MDMA by $4.5 \%$ and cocaine by $4.1 \%$ of 17 -year-olds (lifetime prevalence).

The relatively high use of hallucinogens and ketamine is interesting from the point of view of monitoring drug use trends in Slovenia in the period before the epidemic; the use of synthetic cathinones has been declining for some time in comparison with previous years (Sande, 2016; Sande et al., 2018). An increase in the use of hallucinogens and ketamine before the epidemics was also observed in outreach work and drug testing at the DrogArt Association. The perceived increase in the use of hallucinogens and ketamine among people who use drugs in Slovenia will need to be monitored, as the prevalence of use in the general population in the EU remains low (EMCDDA, 2019).

During the epidemic, there was a strong emphasis on general preventive measures on movement restrictions, hygiene, disinfection, physical distancing, and the use of protective masks in public places. In the sample, just under a fifth of respondents used drugs at private parties in the same group of people. A small proportion of respondents indicated that they used drugs at private parties with a variety of individuals, which, according to the EMCDDA recommendations associated with the COVID-19 epidemic, may pose an increased risk of transmission (EMCDDA, 2020a). The majority of respondents in the sample followed recommendations when using drugs or chose ways where the chances of transmitting infections were lower.

During the epidemic, users followed general recommendations for reducing the risks of drug use. It is encouraging that only a small proportion of users did not follow any of the listed harm reduction recommendations, which indicates that the target group is relatively well informed. Just under a quarter also followed individual COVID-19-specific harm reduction recommendations. This means that they disinfected their 
DRUŠ. ISTRAŽ. ZAGREB GOD. 30 (2021), BR. 2, STR. 313-332

SANDE, M. ET AL. HOW HAS THE... hands before handling drugs, did not share rolls of tobacco or marijuana with others, and used their own clean sniffing utensils. Specific recommendations on reducing the risks associated with drug use during the epidemic were available as a translation and adaptation of the EMCDDA recommendations on the NIJZ website (Drev et al., 2020) and through the social networks of the DrogArt Association, and the general instructions in relation to the epidemic were prepared by the NIJZ (Koronavirus ..., 2020). Nearly half of the respondents did not receive information on drug harm reduction during the epidemic from any source, and just over a fifth received information via the internet and via DrogArt channels, indicating the importance and relatively good reach of the web channels in informing the target group during the epidemic. Such access to information is all the more important because the epidemic has limited people's access to health and social care institutions, which has consequently been reflected in the estimation of more difficult access to support by the respondents.

According to the findings of our research, the epidemic has also had consequences on the drug market in Slovenia. Due to restrictions on movement, fewer people obtained drugs through acquaintances and dealers, and the "home delivery" of drugs by dealers did not change in our sample. The majority of the respondents did not notice any changes in the drug market during the epidemic, and a rise in drug prices was reported by a tenth of the users. A quarter of the respondents cited a smaller number of dealers and a shortage of certain drugs on the market among the changes observed in the drug market during the epidemic. Findings regarding the shortage of certain drugs can be linked to the findings in the UNODC report (Me et al., 2020), while the quality of drugs in Slovenia has decreased only according to a small number of the respondents. The EMCDDA report on the impact of the epidemic on the EU drug market (EMCDDA and Europol, 2020a) states that the impact of online channels on drug purchase and delivery increased during the epidemic, which cannot be confirmed in Slovenia according to the results of our research, since the internet/darknet remains a marginal source of drug access even during the epidemic. The perceived decline in drug purchases through various sources coincides with reduced drug use during the epidemic in our sample. Drug availability has declined slightly for marijuana and cocaine, the two most commonly used drugs in the sample, according to reports from some other EU member states (EMCDDA and Europol, 2020a).

According to the preliminary findings of the EMCDDA study (2020b), the availability of drug services in the EU 
DRUŠ. ISTRAŽ. ZAGREB GOD. 30 (2021), BR. 2, STR. 313-332

SANDE, M. ET AL.: HOW HAS THE... decreased during the first two months of the pandemic, which applies to both therapeutic and harm reduction programmes. The lower accessibility can also be confirmed with regard to the data obtained from our sample of users, which indicated the lower availability of sources of support during the epidemic in Slovenia. Medical institutions, non-governmental organizations and social work centres were less accessible.

What can we learn from the preliminary findings of the described research and our research before the end of the pandemic with the SARS-CoV-2 virus or a similar virus? The results suggest that restrictions on movement and quarantine affected people's increased mental distress, and the sources of support were less accessible or inaccessible. Therefore, it is important to implement adaptations to the programmes which, in accordance with the EMCDDA report (EMCDDA, 2020b), already use mobile or online platforms to communicate with users, reducing the issues of restricting personal contacts. During the epidemic, the DrogArt Association also successfully switched to online interventions to ensure contact and increase the scope of counselling and therapeutic work online due to the interruption of nightlife and contact with our users in the day centre and in the day outreach work. Taking into account the information we have shared through online channels may indicate the effectiveness of online interventions. The transition to online interventions could also be successful because the users of our organization were more accustomed to the use of Internet and social media. Some other organizations working with young people have also successfully adapted to the situation, offering, for example, online consultation and online day centres (e.g. the Mladi Zmaji Public Institute, Logout - Nora Institute, DIC Legebitra Association, Transakcija Institute). Among the organizations working with people who use drugs, online consulting was carried out during the epidemic by the Projekt Človek Association, while other non-governmental organizations, due to the nature of their work and poorer digital competencies of users (e.g. Kralji ulice, Svit Koper, Stigma), carried out work in the traditional format, with adjustments and restrictions in place to prevent the spreading of the epidemic.

According to the results of the research, it will be necessary to inform users intensively about these new channels and to facilitate their access to drug and other support services during contact restrictions. Even in the event of a positive recovery from the crisis, some new online ways of helping and communicating with users could be retained and encouraged. Regardless of the way of overcoming the crisis, given the predicted long-term economic consequences, the priorities in drug services are likely to be aimed at resolving the 
DRUŠ. ISTRAŽ. ZAGREB GOD. 30 (2021), BR. 2, STR. 313-332

SANDE, M. ET AL.: HOW HAS THE..

\section{FUNDING}

\section{NOTES}

\section{REFERENCES}

hardships that will be associated with exacerbated financial situations and job loss or homelessness in addition to using drugs. A special challenge will also be presented by the relaunch of nightlife and related outreach work after the epidemic. Clubs and discotheques remain closed due to the uncertain epidemiological situation, but with the changing restrictions on gatherings, parties still take place indoors. This poses a particular challenge for harm reduction programmes and the staff included in these programmes, as deteriorating conditions may require new guidelines for outreach work in environments where there is a high risk of transmission of infections. These environments will remain at a higher risk for infection transmission even with an improved epidemiological situation, so an integrated approach and cooperation between harm reduction programmes, event organizers and decision-makers to address the issue is crucial for work in this area.

The research, part of the project "Reducing the harmful effects of club drugs among young people" no. C2711-20-708356, was funded by the Ministry of Health of the Republic of Slovenia. Funding did not affect the results of the research.

${ }^{1}$ In showing the results of how often respondents would go out, we combined the answers "often" and "very often".

${ }^{2}$ During the epidemic, DrogArt published information on reducing the risks of drug use during the epidemic on various social networks.

${ }^{3}$ The first number in parentheses represents access before the epidemic and the second during the epidemic.

${ }^{4}$ Under the central scenario, economic growth in the euro area will decline by $8.7 \%$ according to the ECB forecast.

Awaworyi Churchill, S., \& Farrell, L. (2017). Alcohol and depression: Evidence from the 2014 health survey for England. Drug and Alcohol Dependence, 180, 86-92. https://doi.org/10.1016/j.drugalcdep.2017.08.006

Brooks, S. K., Webster, R. K., Smith, L. E., Woodland, L., Wessely, S., Greenberg, N., \& Rubin, G. J. (2020). The psychological impact of quarantine and how to reduce it: Rapid review of the evidence. The Lancet, 395(10227), 912-920. https://doi.org/10.1016/S0140-6736(20)30460-8

Drev, A., Hočevar Grom, A., Jandl, M., \& Kvaternik, I. (2020). Posledice COVID-19 za uporabnike drog in ponudnike storitev obravnave in pomoči [The implication of COVID-19 for people who use drugs and drug service providers]. NIJZ.

EMCDDA - European Monitoring Centre for Drugs and Drug Addiction (2019). European Drug Report 2019: Trends and Developments. Publications Office of the European Union. 
DRUŠ. ISTRAŽ. ZAGREB GOD. 30 (2021), BR. 2, STR. 313-332

SANDE, M. ET AL.: HOW HAS THE...
EMCDDA - European Monitoring Centre for Drugs and Drug Addiction (2020a). EMCDDA update on the implications of COVID-19 for people who use drugs (PWUD) and drug service providers. EMCDDA.

EMCDDA - European Monitoring Centre for Drugs and Drug Addiction (2020b). EMCDDA Trendspotter briefing. Impact of COVID-19 on drug services and help-seeking in Europe. EMCDDA.

EMCDDA - European Monitoring Centre for Drugs and Drug Addiction (2020c). Impact of COVID-19 on patterns of drug use and drug-related harms in Europe. Publications Office of the European Union.

EMCDDA - European Monitoring Centre for Drugs and Drug Addiction and Europol (2020). EU drug markets: Impact of COVID-19. Publications Office of the European Union.

Jeriček Klanšček, H., Roškar, M., Drev, A., Pucelj, V., Koprivnkar, H., Zupanič, T., \& Korošec, A. (2019). Z zdravjem povezana vedenja v šolskem obdobju med mladostniki v Sloveniji. Izsledki mednarodne raziskave HBSC, 2018 [Health behaviour of adolescents in Slovenia. Results of the HBSC International Survey, 2018.] Nacionalni inštitut za javno zdravje.

Kim, S., \& Park, T. (2019). Acute and chronic effects of cocaine on cardiovascular health. International Journal of Molecular Sciences, 20(3), 584. https://doi.org/10.3390/ijms20030584

Koronavirus (SARS-CoV-2) - ključne informacije [Coronavirus (SARS-CoV-2) - basic information] (2020). https://www.nijz.si/sl/koronavirus-2019-ncov

Me, A., Zeiler, I., \& Garcia Yi, J. (2020). COVID-19 and the drug supply chain: From production and trafficking to use. UNODC Research and Trend Analysis Branch.

Mitchell, C. A., Pitt, A., Hulin, J., Lawson, R., Ashby, F., Appelqvist, I., \& Delaney, B. (2016). Respiratory health screening for opiate misusers in a specialist community clinic: A mixed-methods pilot study, with integrated staff and service user feedback. BMJ Open, 6(10), e012823. https://doi.org/10.1136/bmjopen-2016-012823

Napovedi makroekonomskih gibanj v Sloveniji [Forecasts of the macroeconomic developments in the Republic of Slovenia] (2020). Banka Slovenije, Ljubljana. https://bankaslovenije.blob.core.windows.net/publicationfiles/napovedi-makroekonomskih-gibanj-junij-2020.pdf

Nicola, M., Alsafi, Z., Sohrabi, C., Kerwan, A., Al-Jabir, A., Iosifidis, C., Agha, M., \& Agha, R. (2020). The socio-economic implications of the coronavirus and COVID-19 pandemic: A review. International Journal of Surgery, 78, 185-193. https://doi.org/10.1016/j.ijsu.2020.04.018

Odlok o začasni splošni prepovedi gibanja in zbiranja ljudi na javnih krajih, površinah in mestih v Republiki Sloveniji ter prepovedi gibanja izven občin [Ordinance on the temporary general prohibition of movement and public gathering in public places and areas in the Republic of Slovenia and the prohibition of movement outside the municipality] (2020). Uradni list RS, št. 52/20 (10. 4. 2020). http://www. pisrs.si/Pis.web/pregledPredpisa?id=ODLO2049

Oosterhoff, B., Palmer, C. A., Wilson, J., \& Shook, N. (2020). Adolescents' motivations to engage in social distancing during the COVID-19 pandemic: Associations with mental and social health. Journal of Adolescent Health, 67(2), 179-185. https://doi.org/10.1016/j.jadohealth.2020. 05.004 
DRUŠ. ISTRAŽ. ZAGREB GOD. 30 (2021), BR. 2, STR. 313-332

SANDE, M. ET AL. HOW HAS THE..
Palmer, F., Jaffray, M., Moffat, M. A., Matheson, C., McLernon, D. J., Coutts, A., \& Haughney, J. (2012). Prevalence of common chronic respiratory diseases in drug misusers: A cohort study. Primary Care Respiratory Journal, 21(4), 377-383. https://doi.org/10.4104/pcrj.2012.00069

Rehm, J., Room, R., Graham, K., Monteiro, M., Gmel, G., \& Sempos, C. T. (2003). The relationship of average volume of alcohol consumption and patterns of drinking to burden of disease: An overview. Addiction, 98(9), 1209-1228. https://doi.org/10.1046/j.1360-0443.2003. 00467.x

Remuzzi, A., \& Remuzzi, G. (2020). COVID-19 and Italy: What next? The Lancet, 395(10231), 1225-1228. https://doi.org/10.1016/S0140-6736 (20)30627-9

Richter, K. P., Ahluwalia, H. K., Mosier, M. C., Nazir, N., \& Ahluwalia, J. S. (2002). A population-based study of cigarette smoking among illicit drug users in the United States. Addiction, 97(7), 861-869. https://doi. org/10.1046/j.1360-0443.2002.00162.x

Sande, M. (2016). Characteristics of the use of 3-MMC and other new psychoactive drugs in Slovenia, and the perceived problems experienced by users. International Journal of Drug Policy, 27, 65-73. https://doi. org/10.1016/j.drugpo.2015.03.005

Sande, M. (2020). Sex and nightlife: Risky sexual behavior and young people's attitude toward STIs. American Journal of Sexuality Education, 15(3), 357-370. https://doi.org/10.1080/15546128.2020.1796867

Sande, M., Paš, M., Nahtigal, K., \& Šabić, S. (2018). Patterns of NPS use and risk reduction in Slovenia. Substance Use \& Misuse, 53(9), 1424-1432. https://doi.org/10.1080/10826084.2017.1411366

Schuckit, M. A. (2006). Comorbidity between substance use disorders and psychiatric conditions. Addiction, 101(Suppl 1), 76-88. https://doi. org/10.1111/j.1360-0443.2006.01592.x

Sinha, R. (2008). Chronic stress, drug use, and vulnerability to addiction. Annals of the New York Academy of Sciences, 1141(1), 105-130. https://doi. org/10.1196/annals.1441.030

Smith, J. P., \& Book, S. W. (2008). Anxiety and substance use disorders: A review. Psychiatric Times, 25(10), 19-23.

Thylstrup, B., Clausen, T., \& Hesse, M. (2015). Cardiovascular disease among people with drug use disorders. International Journal of Public Health, 60(6), 659-668. https://doi.org/10.1007/s00038-015-0698-3

Torales, J., O'Higgins, M., Castaldelli-Maia, J. M., Ventriglio, A. (2020). The outbreak of COVID-19 coronavirus and its impact on global mental health. International Journal of Social Psychiatry, 66(4), 317-320. https://doi.org/10.1177/0020764020915212

Vulić-Prtorić, A., \& Macuka, I. (2004). Stresni životni događaji i depresivnost $\mathrm{u}$ adolescenciji $\mathrm{u}$ odnosu na konzumiranje sredstava ovisnosti [Stressful life events and depression in adolescence in relation to the consumption of addictive substances]. In M. Miharija, D. Kramarić, D. Dundović, J. Šerić, D. Majić, J. Splivalo, \& B. Juretić (Eds.), Borba protiv ovisnosti - borba za zdravu obitelj [The fight against addiction - the fight for a healthy family] (pp. 437-444). Vlada Republike Hrvatske, Ured za suzbijanje zlouporabe opojnih droga. 
DRUŠ. ISTRAŽ. ZAGREB GOD. 30 (2021), BR. 2, STR. 313-332

SANDE, M. ET AL. HOW HAS THE..
Winstock, A. R., Davies, E. L., Gilchrist, G., Zhuparris, A., Ferris, J. A., Maier, L. J., \& Barratt, M. J. (2020). Global Drug Survey special edition on COVID-19: Interim report. http://globaldrugsurvey.com

ZIUZEOP - Zakon o interventnih ukrepih za zajezitev epidemije COVID-19 in omilitev njenih posledic za državljane in gospodarstvo [Act determining the intervention measures to contain the COVID-19 epidemic and mitigate its consequences for citizens and the economy] (2020). Uradni list RS, št. 49 (10. 4. 2020). http://www.pisrs.si/Pis. web/pregledPredpisa?id=ZAKO8190

\section{Kako je epidemija COVID-19 utjecala na upotrebu i tržište droga u Sloveniji?}

\author{
Matej SANDE \\ Pedagoški fakultet, Sveučilište u Ljubljani, Ljubljana, Slovenija \\ Simona ŠABIĆ, Mina PAŠ, Marko VERDENIK \\ Udruga DrogArt, Ljubliana, Slovenija
}

Svrha našeg istraživanja bila je istražiti kako je epidemija COVID-19 utjecala na upotrebu droga i tržište droga u Sloveniji. Internetskim upitnikom obuhvatili smo nereprezentativni uzorak od 680 liudi koji su konzumirali droge prije i tijekom epidemije 2020. Upotreba ilegalnih droga i alkohola smanjena je. Značajno povećanje učestalosti upotrebe zabilježeno je samo s marihuanom. Najistaknutije promjene na tržištu droga bile su pad dilera i manja dostupnost određenih droga. Pristup uslugama za korisnike droga smanjen je, a ispitanici su imali i znatne financijske posljedice zbog gubitka posla. Zbog slabe dostupnosti izvora podrške u vrijeme epidemije, prilagodbe pružatelja usluga korisnicima droga potrebne su prije kraja pandemije, u smislu promicanja internetskih intervencija i održavanja kontakta s korisnicima kada usluge nisu fizički dostupne.

Ključne riječi: COVID-19, tržište droga, usluge za korisnike droga, mentalno zdravlie, upotreba droga

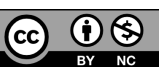

Međunarodna licenca / International License: Imenovanje-Nekomercijalno / Attribution-NonCommercial 